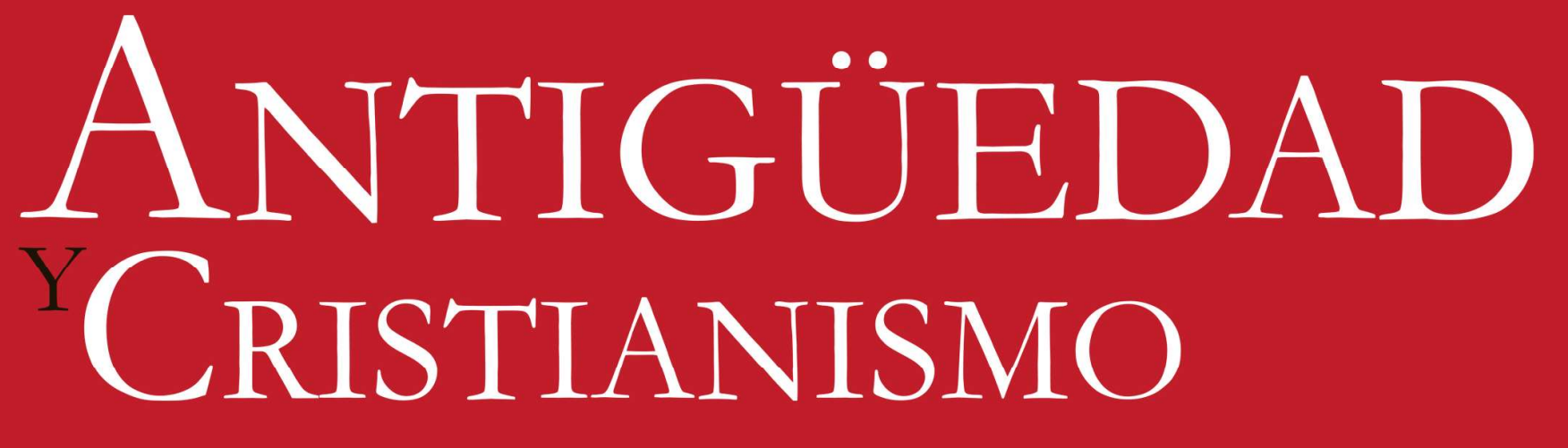

NUEVA ÉPOCA

\title{
n³8 2021
}

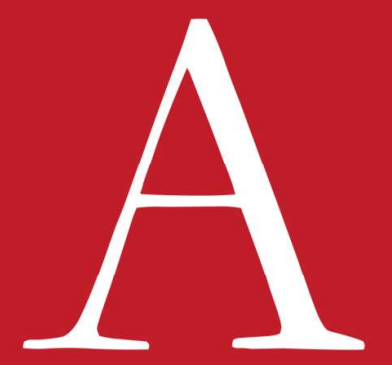

REVISTA DE ESTUDIOS SOBRE ANTIGÜEDAD TARDÍA

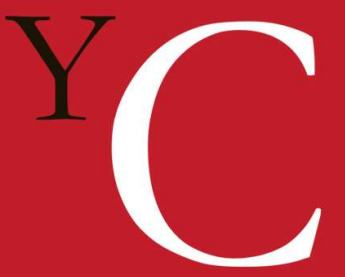

UNIVERSIDAD DE MURCIA 


\title{
ANTigüEDAd y CRISTIANISMo
}

\author{
No 38
}

AÑO 2021

La revista Antigüedad y Cristianismo es una revista científica, especializada en la Antigüedad Tardía y publicada anualmente por la Universidad de Murcia. Fundada en 1984 por el catedrático Antonino González Blanco, acogiendo siempre una amplia diversidad de artículos, noticias y contribuciones siempre originales en todos los campos de la Tardoantigüedad (cultura material, fuentes literarias, mentalidad, historiografía, repertorio de novedades y crítica de libros).

El rasgo distintivo de la línea editorial de esta revista es su búsqueda de aportaciones originales, claras, de carácter inédito, que vayan a hacer una aportación nueva, profesional y metodológicamente solvente, que sea significativa en el ámbito de los estudios de la Tardoantigüedad. La veracidad y honestidad son las señas de identidad más preciadas para la revista Antigüedad y Cristianismo.

\author{
Departamento de Prehistoria, Arqueología, Historia Antigua, Historia Medieval y CC.TT.HH. \\ Área de Historia Antigua \\ Universidad de Murcia
}

Directores: Rafael González Fernández (Univ. de Murcia, España) y José Antonio Molina Gómez (Univ. de Murcia, España)

Secretarios de redacción: Pedro David Conesa Navarro (Univ. de Hamburgo, Alemania) y José Javier Martínez García (Univ. de Murcia, España).

Consejo de Redacción: Alejandro Andrés Bancalari Molina (Univ. de Concepción, Chile), Juan Jesús Botí Hernández (Univ. de Murcia, España), Adolfo Díaz Bautista (Univ. de Murcia, España), David Hernández de la Fuente (Univ. Complutense de Madrid, España), Helena Jiménez Vialás (Univ. de Murcia, España), Miguel Martínez Sánchez (Univ. de Murcia, España), Jordina Sales-Carbonell (Universitat de Barcelona, España), Amparo Mateo Donet (Univ. de Valencia, España), Diego Melo Carrasco (Univ. Adolfo Ibáñez de Santiago de Chile), Julio César Muñiz Pérez (Univ. Internacional de La Rioja, España), Juan Carlos Olivares Pedreño (Univ. de Alicante, España), Yolanda Peña Cervantes (Univ. Española de Educación a Distancia, España), José Soto Chica (Univ. de Granada-Centro de Estudios Bizantinos, Neogriegos y Chipriotas, España), Gerardo Fabián Rodríguez (Univ. Nacional del Mar del Plata, Argentina), Alberto Romero Molero (Univ. Isabel I, España), Miguel Pablo Sancho Gómez (Univ. Católica de Murcia, España), Ester Sánchez Medina (Univ. Autónoma de Madrid, España), Héctor Uroz Rodríguez (Univ. de Murcia, España), Isabel Velázquez Soriano (Univ. Complutense de Madrid, España), Jaime Vizcaíno Sánchez (Univ. Complutense de Madrid, España).

Comité Científico y Asesor: Juan Manuel Abascal Palazón (Univ. de Alicante, España), Mirta Beatriz Álvarez Mallada (Univ. de Buenos Aires, Argentina), Hassan Ibrahim Amer (Cairo University, Egipto), Pedro Barceló y Batiste (Universität Potsdam, Alemania), Aldo Brolengui (Université Lumière Lyon 2, Francia), Orietta Dora Cordovana (Università degli Studi di Roma- Roma Tre, Italia), Francisco Cuena Boy (Univ. de Cantabria, España), Rosa María Cid López (Univ. de Oviedo, España), Ma Victoria Escribano Paño (Univ. de Zaragoza, España), Juan José Ferrer Maestro (Univ. Jaime I, España), Antonino González Blanco (Univ. de Murcia, España), Sonia Gutiérrez Lloret (Univ. de Alicante, España), Elisabetta Interdonato (Université de Lille, Francia), Sabine Lefevre (Université de Bourgogne, Francia), Attilio Mastino (Università degli Studi di Sassari, Italia), José Carlos Miralles Maldonado (Univ. de Murcia, España), Claudio Moreschini (Università di Pisa, Italia), Johannes Niehoff-Panagiotidis (Freie Universität Berlin, Alemania), Danuta Okoń (Uniwersytet Szczeciński, Polonia), Susana Reboreda Morillo (Univ. de Vigo, España), Gisela Ripoll López (Univ. de Barcelona, España), Rosa Sanz Serrano (Univ. Complutense de Madrid, España), Sabine Schrek (Universität Bonn, Alemania), Francisco Salvador Ventura (Univ. de Granada, España), Chiara O. Tommasi (Università di Pisa, Italia), Margarita Vallejo Girvés (Univ. de Alcalá, España), Edward Watts (University California San Diego, EE.UU.).

La correspondencia de carácter científico habrá de dirigirse al Secretario de la revista

(Facultad de Letras, Campus de la Merced, 30001, Murcia)

Correo electrónico de la revista: ayc@um.es

URL: https://revistas.um.es/ayc/

Los pedidos e intercambios deben dirigirse a: Servicio de Publicaciones de la Universidad de Murcia Edificio Pléiades, Campus Universitario de Espinardo, 30071, Murcia.

ISSN: 0214-7165 - ISSNe: 1989-6182

Depósito Legal: MU-416-1988

Maquetación: José Javier Martínez García 


\section{Índice:}

\section{Artículos}

El empleo del vocablo phantasma en las fuentes literarias latinas: de los primeros registros a los autores cristianos tardorromanos

Raúl Serrano Madroñal

Problemática de estudio en el caso de los retratos de El-Fayum

Consuelo Isabel Caravaca Guerrero

Díon en época cristiana: Pervivenias y cambios

Diego Chapinal Heras

La importancia política y militar de las revueltas bagaudas en época tardorromana Francisco Javier Sanz Huesma

Algunas imágenes del ejército romano en el siglo III (235-284)

Miguel Pablo Sancho Gómez

El rescriptum del emperador Majencio sobre Lucilla de Cartago en vísperas del cisma donatista

Diego Sierra, Marco Cenini, Fabio Manuel Serra y Alessandro Podda

Les cerf - le canthare - les quatre fleuves du Paradis dans la mosaïque chretienne de Tunisie. Les catechumenes et le Bapteme / Les fideles et l'Eucharistie : une contribution a l'iconongraphie paleochretienne d'Occident

Silvio Moreno

¿Episcopus sine ciuitate? La promoción episcopal de centros no urbanos en la Península Ibérica durante la Antigüedad Tardía

Jesús Peidro Blanes

El narrador del Carmen Paschale en el relato de la muerte y resurrección de Jesús $M^{a}$ Dolores Hernández Mayor

Cruces grabadas en la necrópolis rupestre tardoantigua de Tiermes

(Montejo de Tiermes, Soria

Eusebio Dohijo

Harmonization of Calendars in the Early Islamic World as Reflected in alFarghānīs Elements of Astronomy

Razieh S. Mousavi y Jannis Niehoff-Panagiotidis

\section{Recensiones}

Territorio, topografía y arquitectura de poder durante la Antigüedad Tardía, MYTRA 1. Sánchez Ramos, I y Mateos Cruz, P. (Eds.), 2018, 328 pp.

Víctor José Serrano García 
Cómo citar / How to cite: Mousavi, R. y Niehoff-Panagiotidis, J. 2021. Harmonization of Calendars in the Early Islamic World as Reflected in al-Farghānīs Elements of Astronomy. Antigüedad y Cristianismo 38, 203-217. https:/doi.org/10.6018/ ayc. 471611

\section{Harmonization of Calendars in THE EARLy ISLAMIC WORLD AS REFLECTED IN AL-FARGHĀNİ'S ELEMENTS OF ASTRONOMY}

\section{ARMonización DE CALENDARIOS EN EL MUNDO ISLÁMICO PRIMITIVO COMO SE REFLEJA EN ELEMENTOS DE ASTRONOMÍA DE AL-FARGHĀNī}

\author{
Razieh S. Mousavi \\ Max Planch Institute for the History of Science, \\ Berlin, Germany \\ rmousavi@mpiwg-berlin.mpg.de \\ orcid.org/0000-0002-0263-8548
}

\author{
Jannis Niehoff-Panagiotidis \\ Freie Universität, \\ Berlin, Germany \\ jnp@zedat.fu-berlin.de \\ orcid.org/0000-0001-7253-4317
}

Recibido: 3-3-2021

Aceptado: 2-6-2021

\section{RESUMEN}

Este artículo pretende arrojar luz sobre los conocimientos calendáricos en los primeros siglos de la era islámica, en los que diferentes tradiciones administrativas quedaban bajo el control de un gobierno central. La astronomía, como disciplina patrocinada por la corte en la dinastía abasí (132-656 /750-1258), emprendió la tarea fundamental de identificar y dominar varias disciplinas calendáricas bajo el reinado de los califas para hacer viable una gestión centralizada. En los dos primeros siglos, el dominio del calendario lunar árabe, cuya importancia radica en la regulación de las fiestas y ocasiones anuales islámicas, provocó drásticos desacuerdos con los ciclos anuales de siembra que seguían los agricultores. En consecuencia, el sistema fiscal oficial se enfrentó a graves problemas, cuya solución fue el desarrollo de un calendario solar bien establecido. La gran preocupación de los astrónomos musulmanes del siglo IX por los cómputos calendáricos reconoce su participación integral en este desafío ejecutivo. El presente estudio sigue estas prácticas a través de la atenta lectura de un texto astronómico árabe del siglo IX escrito por Ahmad b. Muhammad b. Kathīr al-Farghānī (Alfraganus en occidente), conocido principalmente como los Elementos de Astronomía. La cuidadosa exploración de este texto nos ayuda a conseguir una imagen más amplia de los relatos sobre el tiempo en la primera época islámica y la necesidad de las conversiones calendáricas. Además, el informe detallado del autor sobre los cinco calendarios existentes en la época (árabe, siríaco, bizantino, persa y egipcio) y sus sistemas de nomenclatura, abre una posibilidad para la investigación lingüística de la relojería en el mundo islámico.

Palabras clave: Astronomía, islam, Aḥmad al-Farghānī, tradición, Antigüedad Tardía.

\section{Abstract}

This paper seeks to shed more light on calendrical knowledge in the first centuries of the Islamic era in which different administrative traditions fell under the control of a central government. Astronomy as a court-sponsored discipline in the Abbasid dynasty (132-656 AH/750-1258 CE), 
undertook the pivotal task of identifying and mastering various calendrical disciplines under the reign of the caliphs to make a centralized management feasible. In the first two centuries, the domination of the Arabic lunar calendar, whose significance lies in governing the Islamic yearly festivals and occasions, led to drastic disagreements with the annual planting cycles that were followed by the farmers. Accordingly, the official taxation system faced serious problems, the solution of which was the development of a well-established solar calendar. The large concern of the ninth-century Muslim astronomers for calendrical computations acknowledges their integral participation in this executive challenge. The present study follows these practices through the lens of a ninth-century Arabic astronomical text, written by Ahmad b. Muhammad b. Kathir al-Farghāni (Alfraganus in the west), known mainly as the Elements of Astronomy. The careful exploration of this text helps us achieve a broader image of time-keeping accounts in the early Islamic era and the need for calendrical conversions. Moreover, the author's detailed report of the five existing calendars of the time (Arabic, Syriac, Byzantine, Persian and Egyptian) and their systems of nomenclature, opens an early window to the linguistic investigation of time-reckoning in the Islamic world.

Keywords: Astronomy, Islam, Aḥmad al-Farghānī, Tradition, Late Antiquity.

\section{SUMARIO}

1. Introducción. 2. Calendrical Questions of the Ninth Century. 3. In Synchrony of Different Calendars. 4. Concluding Remark.

\section{INTRODUCTION}

The treatise under investigation here is compiled in the middle of the ninth century by al-Farghānī, an eminent Muslim astronomer who allegedly took part in the courtly astronomical observations during the time of caliph al-Ma'mūn (r. 198-218 AH/813$833 \mathrm{CE})^{1}$. Nothing specific is known about al-Farghānīs life, but according to his familyname, it seems reasonable to trace his lineage back to Farghāna, a major Transoxianan city and landscape. He earned his unique reputation in the history of Medieval astronomy for the wide circulation of his wellstructured exposition of Ptolemaic theories known as the Elements of Astronomy through Arabic and Latin translations ${ }^{2}$. Despite alFarghānī's deviation from Ptolemy in a few

1 Șāid al-Andalusī (1997, 225) openly supports al-Farghānīs activities as an astronomer at al-Ma'mūn's court, although he does not provide details.

2 A list of its Medieval Latin translations has been provided by Carmody 1956, $113-116$. subjects, the nucleus of the work remains loyal to Ptolemaic astronomy. This is done in a way that it was occasionally labelled as a summary of the Almagest which probably played a role in its vast popularity. Backed by a high level of authenticity, the Elements of Astronomy safely grafted non-Ptolemaic elements to the fertile ground of the nascent Islamic astronomy. One of these additions appears in the first chapter, where the main concern of the author is a comparative study of the five calendars in function in his time: Arabic (lunar), Syriac, Byzantine, Persian, and Egyptian (Coptic). The fact that this practical topic is addressed in the opening chapter of his work calls for careful attention. In the first part of our study, we approach this question by observing the sociocultural sphere of the ninth century, in which al-Farghāni turns into a protagonist in the activities regarding calendrical issues. Through this analysis, we will see how an attempt for the standardization of the applied annuals was carried out by ninth-century astronomers. 
The second part of this paper is devoted to a technical investigation of the surveyed calendars in al-Farghānīs chapter while also tracing their historical and philological origins in the surviving sources. Furthermore, the discrepancies found in the extant Arabic manuscripts come to our focus. In relation to these, we discuss computational materials and the dialectical divergences that are disseminated through the textual transmission of the Elements of Astronomy.

It should be noted from the start that this article is the result of a collaboration between a specialist in mathematical astronomy and a historian-philologist in the field of Byzantine and Oriental Studies. The latter uses his knowledge for the elucidation of some of the historical/philological problems of the aforementioned chapter of al-Farghānī, particularly where the Byzantine calendars are concerned (Coptic, Greek, Syriac), while not entering the technical part. A comprehensive discussion of most issues raised in this study will be carried out in the framework of the first author's doctoral project ${ }^{3}$.

\section{Calendrical Questions of the Ninth Century}

Al-Farghānīs Elements of Astronomy is among very few well-preserved astronomical compilations reaching us from the early Islamic period. Our knowledge of the Muslim contributions in the first three centuries is very fragmentary and lacks verification. Some are only known to us through quotations, revisions and translations of later authors and survive

3 This paper benefits largely from an Arabic critical edition of the Elements of Astronomy in the first author's doctoral dissertation which is currently in process at the Humboldt University of Berlin and generously supported by the Max Planck Institute for the History of Science. She expresses warm appreciation to her Ph.D. supervisors, Prof. Jürgen Renn and Prof. Klaus Geus for their unfailing encouragement. The authors also wish to thank Dr. Flora Vafea, for her generous reading and commenting on the first draft of this paper which lead to greater amount of clarity. in single copies ${ }^{4}$. In these circumstances, the fact that the Elements of Astronomy exists in eighteen copies from diverse time-periods underlines its importance. Moreover, the differences between surviving copies and commentaries, translations, and quotations ${ }^{5}$ made upon al-Farghānīs text are so limited, that we can safely assume to have access to a text that is very close to the original version that left the hands of its author. In light of this credibility and widespread circulation ${ }^{6}$, this paper will track calendrical knowledge of the early Islamic centuries on both textual and contextual levels.

Al-Farghānīs text, which he himself introduces in the first sentence as Jawāmi 'ilm al-nujūm wa uṣūl al-ḥarakāt al-samāwīya (Compendium of the Knowledge of Stars and the Elements of Celestial Motions), begins with a chapter on chronology. The structure and content of this chapter stands apart from the next twenty-nine chapters which focus predominantly on Ptolemaic astronomy. Here, he gives a taxonomic conspectus of the different methods of time-reckoning among the people of his temporal and geographical horizon in clear technical Arabic. We have little certain knowledge about the calendars used by pre-Islamic Arabs. But there is no large amount of disagreement over the fact that

4 Sindhind $Z_{\bar{j}} j$ by Al-Khwārizmīi is a good example of this inadequacy which is extant only in a Latin translation of a recension made by al-Majrịtị (Cordoba, c. 980) and is too far distant from the original text. For detailed information, see Neugebauer (1962, esp. 8 - 9); van Dalen (1996, 200 and 246).

5 Two available Arabic commentaries on the Elements of Astronomy, by al-Qabīsī (d.356/967) and al-Jūzjānī (d.462/1070), the pupil and biographer of Ibn Sinnā, have been observed by the authors of this paper. Our claim on the stability of al-Farghānīs text is also based on consulting K. al-A 'àq al-nafisa by Ibn Rusta, a 10th century Persian geographer and traveller, in which five chapters of the Elements of Astronomy are quoted word for word.

6 As mentioned above, an already unpublished Arabic critical edition of the Elements of Astronomy built upon surviving manuscripts has been employed in this paper. An incomplete yet extensive list of extant manuscripts is available online at https://ismi.mpiwg-berlin.mpg. de/text/136041 (ISMI: Islamic Scientific Manuscripts Initiative, accessed on 10 June 2020). 
they utilized vague methods of intercalation to keep a lunar calendar in step with the seasonal cycle ${ }^{7}$. Early Islamic astronomy was strongly influenced by Sasanian-Indian traditions. Through this the Persian Yazdgirdī calendar infiltrated into the Islamic astronomical discipline to the extent that it gained primacy over the other options ${ }^{8}$. A Persian year consists of 365 days, divided into twelve months of 30 days each, plus five supplementary days added to the end of the eighth month (Ābānmāh). This concrete simple structure made it a good candidate for astronomical periodic computations ${ }^{9}$. However, since it is primarily utilized in scientific-astrological activities, it hardly made its way into the official calendrical system. Taxational years were counted based on Arabic lunar time-reckoning, although Persian feasts, like Nawrūz, remained culturally in use in the eastern provinces of the caliphate as the opening dates for tax collection. This discordant application of two chronological settings caused a certain amount of confusion. Even worse, following the fall of the Sasanian empire, intercalation was no longer implemented and thus, Persian months began to circulate through the course of a solar revolution. It eventually led to an unsynchronized calendar from the solar year in which farming phases occurred out of season. In the first half of the ninth century, Nawrūz receded one season, from summer to spring, forcing landholders to pre-sell their green crops in order to pay their taxes. It led to increasing dissatisfaction with the central government and thereby an administrative

7 For an extensive discussion on pre-Islamic intercalation methods in Arabic Peninsula see Nallino 1911, 84-104.

8 See Pingree 1968, 100 in which surviving fragments of astronomical works by Ya qūb b. Țāriq (fl. late 2thc. $\mathrm{AH} / 8$ th c. $\mathrm{CE}$, Baghdad) are introduced and investigated. Ya 'qūb b. Tāriq is known as one of the representatives of the earliest Islamic astronomers. According to Pingree's research, the Persian calendar was remarkably used in his writings.

9 Al-Bìrūnì $(1878,31)$ links the wide usage of Persian calendar in zìjes to its practical simplicity (li-suhülat al'amal bihī). action to relieve the demand for calendrical reform became expected.

According to some accounts, the restoration of Sasanian intercalary periods was proposed earlier by Persian taxpayers but failed to convince the caliphs. Al-Bìrūnī (362-c.440 $\mathrm{AH} / 973-\mathrm{c} .1048 \mathrm{CE})$ suggests that this relates to their fear of being accused of supporting Zoroastrianism ${ }^{10}$. That a year consists of twelve months is attested to in the Qur'a an (9: 336 - 37) in which any manipulation of this amount and functioning "nasì" is strongly prohibited. There is no consensus among the commentators of the Qur'an as to the precise meaning of nasì. It is historically evident, however, that to some early readers of the Qur'an it implied the correspondence of the Arabic lunar calendar to the natural (solar) year and, consequently, the implementation of intercalary cycles was refrained from ${ }^{11}$. The Persian Yazdgirdi calendar was not the only chronological system practised alongside the Muslim lunar calendar. The Christian solar calendar, based on the Julian regulation was also in use in the western territories. Its mode of intercalation involved adding one day to the standard year of 365 days, once every four years. This seemingly occurred without causing conflict despite working in tandem with the Muslim lunar system of time-keeping ${ }^{12}$. Faced

10 According to al-Bīrūnī $(1878,31)$, Persian local landowners (dihqāns) raised this suggestion formally at least two times to the courts. First, they asked Hishām b. 'Abdulmalik (r. 105 - 125 AH/ 724 - $743 \mathrm{CE}$ ) who was finally warned to intercalate the Persian calendar and commit a nasì' (v. infra on this issue) and secondly, they contacted the Iranian vizier of Hārūn al-Rashīd (r. 170 - $193 \mathrm{AH} / 786$ - $809 \mathrm{CE}$ ) who refrained from insisting on this reform because of the accusation of carrying Zoroastrian zeal.

11 For a brief review on different interpretations see de Blois 2000, 260. Some narratives link nasī with employment of an intercalation method by pre-Islamic Arabs in which one month was added every two or three years. In another group of witnesses, nasi is said to be connected with the four pre-Islamic sacred months verified later in Qur'ān.

12 Al-Maqrīzì (1924, 265 - 266, ed. Wiet) evidently reports that rūmi months were in use in Syria, Peninsula and Mosul while facing no discrepancy with the solar cycle and the civil calendar. According to him, this was also true 
with multiple traditions in their communities, Muslim scholars expanded their perspective of the problem and its possible solutions through comparative research. Their suggestion was to maintain the correspondence between Yazdgirdī and Julian calendars, to exculpate the caliph from the stigma of nasì'. Available sources are not unanimous about the official operation of this calendrical reform at the time of caliph al-Mutawakkil (r. $232-247 \mathrm{AH} / 847$ - $861 \mathrm{CE}$ ), however, it is largely accepted that questions regarding this issue were pursued openly at his court ${ }^{13}$. What is interesting for this paper is that this time-period coincides with the period in which al-Farghānī flourished and actively participated in some courtly executive projects $^{14}$. This contribution depicts him as a close observer of the discussion. According to solid evidence, the attempt to postpone the festival of Nawrūz eventually came to fruition about a half century later, during the reign of caliph al-Mu tadid (r. $279-289 \mathrm{AH} / 892-902$ CE) when a calendrical reform was officially announced and implemented. In $282 \mathrm{AH} / 895$ $\mathrm{CE}^{15}$, Nawrūz was returned to summer from its current position in spring. Furthermore, a Julian system of four yearly intercalation was ordered to be regularly applied to the Persian Yazdgirdi calendar to make it stable through the course of a solar year. In accordance with this adaptation, no drastic change happened to the Persian arrangement of months and days except for the introduction of six, instead of five, intercalary days in every four years. This

in Egypt and its environs where the Coptic calendar was considered for tax collection.

13 Al-Bīrūnī $(1878,32)$ trusting his sources reports that in $243 \mathrm{AH} / 858 \mathrm{CE}$, al-Mutawakkil ordered the fixation of Nawrūz on the 17th June (Hazirān), but this reform was left unfinished after his sudden murder.

14 Al-Farghānīs name appears in two construction projects during al-Mutawakkil's time: a Nilometer in Cairo, and a water canal for the planned new capital of the caliphate: see Sabra 1971.

15 This date here is taken from al-Maqrīzīs report (1924, 266, ed. Wiet), apparently derived from the historian al-Tabari (d. $310 \mathrm{AH} / 923 \mathrm{CE}), 10: 39$. There is no agreement among Islamic sources on the exact date of this calendrical change. For this see Taqizadeh 1937, 157: footnote 312 . calendrical reform, later known as "Mu tadidì calendar", had a lasting impact on Muslim financial bureaucracy.

The Mu'tadidì calendar was exclusively destined to regulate the taxational year and save the farmers (and perhaps other seasonal workers like fishermen) from the bother and inconvenience of paying off-season taxes. Therefore, it never took over for the lunar religious-civil calendar. However, the $\mathrm{Mu}$ taḍidì calendar was implemented for a long time in Persia ${ }^{16}$ and Egypt ${ }^{17}$. Since the adjustment of fiscal years was restricted to governmental decisions with no automatic procedure, it was sometimes subjected to ignorance. Tagizadeh $(1939,109)$ speculates that Zoroastrian Persians were particularly reluctant to permit any changes to their traditional mode of calendar and did not support the addition of a bissextile day every four years ${ }^{18}$. Another factor which increased

16 Ibn Wahb (4th c. AH /10th c. CE) 1967, 392, who provides detailed information about administrative manuals, reports that two dates, lunar Arabic and Solar Kharāj year, were registered by officials for financial documents of the Abbasid courts to avoid misuses and injustice. For more examples of the usage of the solar fiscal calendar for financial purposes, see Taqizadeh 1939a, 907 - 908. Fixing Nawrū $z$ at the beginning of summer, caused a seasonal difference from what is currently in use today in which Nawrūz is celebrated in spring. Accordingly, for years, Nawrūz and the first month of the Persian calendar, Farvardin-māh were assigned to summer, and as a result, the fourth month, Tir-māh, was known as the opening month of autumn which remarkably appears in Persian literature. See, for instance, Mas 'ùdī 2003, introduction: $28-30 ; 31$.

17 Al-Qalqashandì (756 - 821 AH/ 1355 - $1418 \mathrm{CE})$ confirms that the taxational year was still in use in Iraq and Persia at his time (1913 - 1922, 2: 390).

18 It is said that Zoroastrians in the western part of Iran shifted the addition of five extra days to the end of the last month instead of its former place at the end of the eighth month: see de Blois 2000, 261. Kūshayār (c. $332-416 \mathrm{AH} / \mathrm{c}$. $944-1025 \mathrm{CE}$ ) suggests that this reform occurred in 375 AY (i.e. Anno Yazdgird) and reports that in some northern parts of Iran, the older tradition was still respected at his time (Bagheri 2006, $20-21 ; 30-31$ ). Another witness for this shift appears in Shahmradān's book (written in $466 \mathrm{AH} / 1074 \mathrm{CE}$ ) where he maintains that Isfandārmad-māh, the last month of current Persian calendar has 35 days, openly opposing those who consider $\bar{A} b \bar{a} n-m \bar{a} h$ (the eighth month) consisting of 35 days. He, 
the amount of confusion were the attempts to harmonize the solar budget years with their lunar counterparts. Because the lunar calendar falls one year forward, once in every 33 solar years, the plan was to drop one fiscal year every 33 cycles. This operation, known as Izdilāq, required the systematic care of passing years which could not be centrally managed through changing dynasties and policies ${ }^{19}$. Gradually, therefore, the necessity of a new reform was accepted by the governments. The creation of the Jalāli calendar (adopted on $471 \mathrm{AH} / 1079$ $\mathrm{CE})^{20}$ was a response to this need.

Following a brief history of al-Mu'tadid's calendrical reform inaugurated at the time of caliph al-Mutawakkil, we now return to the protagonist of our paper, al-Farghānī, who wrote the Elements of Astronomy at the very beginning of this period. We will see in the following sentences of this chapter, how the hot debate regarding tax-calendars noticeably left its mark on al-Farghānīs text. As expected, however, this thread of influence on a ninthcentury astronomical text is not discernible through the content alone and calls for closer inspection. In the previous discussion we saw that the Persian Yazdgirdi calendar served as a foundational ground for computational astronomy in the early Islamic centuries through which long periods of planetary motions became handily calculable. As a result of the relative openness of early Islamic sciences, other calendrical systems were also treated in astronomical handbooks and accompanying tables were devoted to making the conversion of dates possible. All Islamic zijes (astronomical tables with instructions) dedicate an opening section to chronology including information on different eras and

like Kūshyār, assumes that supplementary days should be added to the month ending at Aries $(2003,19)$.

19 Al-Maqrīzī (1924, 263, ed. Wiet) explains that employment of Izdilāq was a technique used to escape from committing nasī [In Wiet's edition Izdilāq is recorded as Izdiläf. For more information on this different reading see Taqizadeh 1939a, 908: footnote 1].

20 A detailed exposition of this calendar can be found in Taqizadeh 1939b, 108-117. calendars ${ }^{21}$. Elements of Astronomy, although distinct in genre and style, shares this feature with zijes and begins with a descriptive and explanatory introduction to the calendrical knowledge of his time. Investigating the surviving copies of the text reveals that they can be categorized into two major groups with regard to the calendrical material: (1) manuscripts dealing with Persian, Hijra (Islamic lunar), Syriac, Byzantine and Coptic calendars respectively; and (2) those with a sequential change in which Hijra, Syriac, Byzantine, Persian and Coptic calendars appear in turn. This divergence does not include any variation in content and is only limited to the positioning of the subsections. It is also noteworthy that, while the second group is greater in amount, the first covers mainly older witnesses ${ }^{22}$. We contend that the historical context we reviewed above is what gives meaning to the re-arrangement of the material.

The demotion of the Persian calendar in the second group of the manuscripts reminds us of a similar turn in the transmission of the Zijj of al-Khwārizmī (c. 163 - 235 AH/c. 780 - $850 \mathrm{CE}$ ). Although early readers confirm the centrality of the Persian calendar in his astronomical tables ${ }^{23}$, the single surviving manuscript based upon a Latin translation of its tenth-century revision is presented in Hijra dates. Since the extant witness of al-Khwārizmī’s work is far removed from the original, we have little means to track a calendrical displacement there. But the Elements of Astronomy provides us with a safe ground to speculate upon this question. The manner of shifting the base calendar is, in our point of view, rooted in the changing approaches to the scholarly

21 Kennedy 1989, 17.

22 Detailed information on editorial procedures will appear in Mousavi's doctoral dissertation.

23 Ibn Muthannā (4th c. AH/10th c. CE) who wrote a commentary on al-Khwārizmī's $Z \bar{i} j$, confirms that his astronomical tables were computed based on Persian calendar (Goldstein 1967, 24 - 25). Ibn al-Qifțī (568 $646 \mathrm{AH} / 1172-1248 \mathrm{CE}$ ) assigns the variation into Hijra chronology to al-Majrịtị through producing his revision on al-Khwārizmī’s Zīj $(1903,336)$. 
identification of calendrical knowledge. Early Islamic contributions regarding chronology have developed from purely astronomical considerations which gave little care to civil requirements. However, the rise of discussions on keeping the seasons fixed to calendar dates, paved the way for astronomers to play a new role in the Abbasid administrative scene. Instead of prioritizing the Persian calendar as the chief computational instrument in astronomical handbooks, the Arabic Hijra system of time-reckoning became increasingly featured, because of growing concerns about religious congruency. Moreover, the change in arrangement in the second group of the manuscripts in al-Farghānìs text speaks of another contextual influence. After Hijra chronology, Syriac and Byzantine calendars emerge in line surpassing the Persian and Coptic systems. This tactic of re-ordering different disciplines suggests the underlying wish to set precedence to the first pair's intercalary method. This means that the Syriac and Byzantine system of adding a bissextile day every four years to regulate the fiscal year, is seen as preferable to the Persian and Coptic system of supplementing firm 30-day months with fixed extra days ${ }^{24}$. It also signals a desire to acknowledge the caliphal order of harmonizing the Persian Yazdgirdi calendar with respect to the Julian yearly cycle. Considering the low number of the first group of manuscripts alongside the aforementioned contextual analysis and the stability of other chapters, convinces us that the rearrangement of the calendars was exerted either by al-Farghāni himself or at a very early stage of the text's reception ${ }^{25}$. The work Elements of Astronomy

24 A similar categorization of the calendars based on the methods of intercalation is pointed out by alQalqashandī (1913 - 1922, 2: 373, 381) in which he pairs the Coptic and Persian calendars against the Syriac and Byzantine disciplines. Al-Qalqashandī does not mention any source for his classification, however, it shows that this viewpoint was still supported by Muslim scholars.

25 Observing the extant Latin and Hebrew translations of the Elements of Astronomy, confirms the wider availability of the second group of manuscripts. We have no other indication that al-Farghānī provided can be taken as a witness that displays how the cooperation of astronomers in the executive practices of the time led to a major shift in the epistemological status of practical science.

In the following section, we scrutinize the linguistic and technical aspects of al-Farghānīss text through which we observe the process of standardization of the calendrical knowledge within the window of the ninth century. In this exploration, we also deal with a theoretical representation of astral sciences in a time that most authors offered their knowledge in algorithmic tabular formats, which left their audience with less of an opportunity to grasp the underlying principles.

\section{IN SYNCHRONY OF DIFFERENT Calendars}

We saw in the previous part that comparing different calendrical systems and applying them in coordination with each other was an important concern during the ninth century. This is not only true for astronomers, but for the class of udabā' in general since many of them served in official positions. This part of our paper is aimed at identifying the patterns, structures and devices used by al-Farghānī to present a well-organized exposition of the calendars. The way he introduces, deconstructs, and compares different chronological systems, conveys a desire to standardize the timekeeping accounts and to make a user-friendly interface for practical applications. To follow his trajectory of elucidation, we treat the calendars in separate sections based on the second sequence of the manuscripts discussed above which circulated wider and reflects de facto preferences.

\section{(1) Hijra Calendar}

a second version of his work. But we can say for certain that the Persian calendar was his chief concern while shaping the initial form of his chapter on chronology. Not only when discussing the differences between eras, are all calendars compared with the Persian calendar, but the sole chronological system whose name appears in other chapters is the Persian calendar. 
As far as the Arabic-Islamic year is concerned, the author states that this lunar year is comprised of 354 days and that this is a jalil year. In the first group of manuscripts, starting with the Persian calendar, there is no detailed information on the Hijra monthnames and the author is content to mention only the first and the last months (min alMuharramilädhi al-Hajja). The fact that in the second group, Arabic month-names appear and stand in parallel to the structure of the expositions for other calendars, speaks again of their practical prominence. Al-Farghānī explains that for the precise length of a lunar year we need to add eleven days every 30 years. In this sense, the average lunar year has 354 days plus a fifth and a sixth (of a day): fatakūnu hișșatu al-sanatu al-wāḥidatu khamsan wa sudsan yauman ( $=354$ days and 8 hours and 48 minutes). Accordingly, the year in which these additional days are implemented, includes seven complete (tāmma) and five incomplete (nāqișa) months. If observing the moon matters for us for counting the months, al-Farghāni says that complete and incomplete months are not predictable, but the number of the days of the months remains intact (al'adad al-ayyām al-shuhūr huwa bi-l-ḥisāb almușaḥhạh).

\section{(2) Syriac and Byzantine Calendars}

The Syriac calendar (shuhūr al-suryānī) was used by the Byzantines in the Eastern part of their Empire and by the Syriac Christians in Iraq and Iran; regions which once belonged to the Sasanian Empire. These are the old Aramaic (indeed the Babylonian) monthnames, used also by the Parthians and the Sasanians ${ }^{26}$, of pre-Hellenistic origin (adopted

26 To see how the system of different time-reckoning between the Hellenistic Empires of the East functions, one can take a glimpse on the parchments from Avroman in Kurdistan investigated by Minns 1915 (two in Greek, one in Aramaic [with some Iranian words]) from the first $c$. BCE, and the Syriac deed of sales found in Dura Europos dated on May 9243 (ed. and commented by Drijvers and Healey, 232 ff. ). Also the inscriptions from Palmyra bear witness to this interaction, e. g. in the bilingual inscription by the Seleucids) and also used by the Jews (who continue to use the lunar calendar). These names have remained in use even in present time in Greater Syria (bilādal-shām) and Iraq, alongside the Islamic ones. They also form the basis of the modern Turkish monthnames. The reason for this is taxation.

The list of the Syriac month-names in the Elements of Astronomy are as follows: Tishrīn al-awwal (31 days), Tishrīnal-ākhir (30), Kānūn al-awwal (31), Kānūnal-ākhir (31), Shubāṭ (28 or 29 days, also Turkish) -in the latter case (29 days for Sh.), this year is, according to al-Farghānī, a leap year (kabīsa, this is also the Islamic name)- Adhar (31), Nisān (30), 'Ayyār (31), Hazīrān (30), Tammūz (31), Ab (31), Aylūl (30). ${ }^{27}$ This year contains 365 days, with an extra day being added once every four years. This results in there being 365 and a quarter days yearly.

Al-Farghānīs exposition on the Byzantine calendar (shuhūr al-rūm) is the shortest. Rūm here means "Byzantine," as it always does in Islamic sources. Al-Farghānī rightly declares that the months observed by the Byzantines were the same as the Syriac ones. For every Byzantine name he further gives the Aramaic equivalent, these are cited above. It is worthwhile to examine these names here, in order to help determine from which kinds of sources he acquired his information:

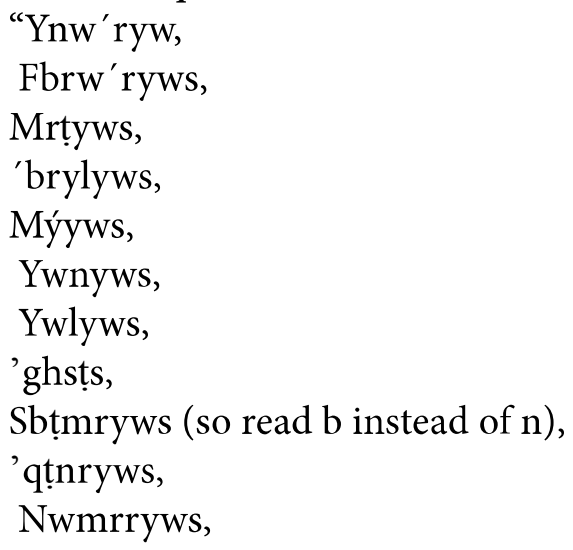

in Greek and Aramaic published recently by Kubiak and Jakubiak(2012), Nr. 3 (Aramaic/Macedonian Month name).

27 Variants of the Arabic month-names in the surviving manuscripts will appear in forthcoming Mousavis doctoral dissertation. 


\section{Dhqmryws."}

These are clearly the original Latin month names as they were in use in the Byzantine Empire and in Greece today; the Ancient Greek month-names did not survive (only G. Pachymeres, a 14th c. Byzantine historian tried to use them again). Consequently, they display a Greek form, which means that the Latin ending is - like decembris - is changed with a tendency for hypercorrection into the Greek เo - like $\Delta \varepsilon \kappa \varepsilon \dot{\varepsilon} \beta \rho$ เoৎ etc ${ }^{28}$. It is important to know that even in Modern Greek there is a difference between the more popular names that end in $(-1 \varsigma)$ and the more official names that end in (The latter longer forms prevail today, while the shorter ones are common in proverbs. Therefore, it is highly probable that al-Farghāni had an official Byzantine list in front of him, maybe even from a Syriac source (where the official Byzantine names appear frequently); he knows the names through written sources, not from spoken Greek. The only exception to this is the form of the name of August, Aghostos, which is evidently a popular Latin form close to Italian Agosto. It is also attested to in Syriac (Brockelmann 4b). From this we can conclude that al-Farghāni was dealing with learned material as the names for the months among the Western neighbours of the caliphate are concerned.

Our author also correctly states that the first day of January corresponds to the first day of Kānūn al-ākhir, when the festival of the qlnds is celebrated. This is clearly the Byzantine feast on the first of January ká $\lambda \alpha v \delta a l$, which is the Byzantine form of the Ancient Roman kalendae, that marks the beginning of the Roman Year. This was a popular festivity in Byzantium that was officially condemned by the Church but is still celebrated in Greece today. Here, Al-Farghānì is giving the (almost) Modern Greek form, кá $\lambda \alpha v \delta \alpha$, which goes back to the old accusative. The different forms of the names are listed in Lampe (696 b) and

28 The list in de Blois 2000, the Julian calendar in the Islamic world, needs revision.
Trapp ${ }^{29}$. The Arabic form is given without vowels, but the subjacent Greek form is clear.

\section{(3) Persian Calendar}

The Persian calendar (shuhūr al-furs) is given more attention than all the other calendars in the Elements of Astronomy. This is perhaps because as an astronomer of Iranian origin he possesses more personal experience with this particular subject. However, he demonstrates no sign of knowledge of the old Sogdian and Khwārizmian calendars which were still currently in use in his native Farghāna valley. These calendars are still mentioned by al-Bīrūnī even centuries later ${ }^{30}$. Our author does not even mention the Armenian calendar, which is also derived from the old Iranian times, but dates from a "pre-reform" (v. infra) period.

While the Armenian calendar is only of limited importance, especially in Baghdad during the ninth century, its absence does highlight the scientifically disciplined method of al-Farghānìs writing, seeing as it comes from his native land. The structure of this section is as follows: Like in the other examples, he first gives a list of the month-names, in the modern sequence, beginning with Farvardīn-māh. The formula always runs $\mathrm{x}+$ māh ("month"). This is exceptional because he does not add e. g. $\mu$ ń $v$ into the other lists. He also includes a list of the 30 Zoroastrian names for the days of the month, which is among the earliest extant witnesses. These names are given below without a detailed philological commentary. This will be further developed in a separate paper and will be based on various extant manuscripts:

"Hrmz, Bhmn, 'rdybhsht, Shhrywar, 'sfnd'rmd, Khrd'd, Mrd'd, Dyb'dr, 'd'r, 'b'n,

29 E. Trapp, Lexikon zur byzantinischen Gräzität (online edition: stephanus.tlg.uci.edu/lbg/\#eid=33698\&conte $\mathrm{xt}=$ search\&type $=$ greek\&term $=$ kaland $:$ accessed on April 22 2020), ss vv. The female plural form appears already in

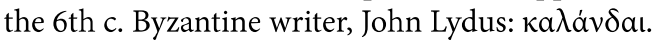

30 Lewy 1941, 37ff. Also, the Mandaeans today use the Iranian month-names, v. Macuch et alii , A Mandaic Dictionary $\mathrm{x}$. 
Khwr, M'h, Tyr, jwsh, Dybhmr, Mhr, Srwsh, Rshn, Frwrdyn, Bhr'm, R'm, B'd, Dybdyn, Dyn, 'rd, 'sht'd, 'sm'n, Z'my'd, M'rsfnd, 'nyr'n."

Most of these names go back to Zoroastrian deities and can also be found in the list of month-names. Even if one considers the unreliability of some manuscripts and the lack of vowel signs, the forms given by alFarghānī are the New Persian forms, not the ones found in Pahlavi (v. the list in Panaino et al. 1990, table 23). Four Zoroastrian festivals are inserted into this list, which is the highest number given for any sort of calendar in the Elements of Astronomy. These are Nawrūz (called Nayrūz, a common Arabic form) on the first of Farvardīn-māh, Mihrjān on the sixteenth of Mihr-māh, the ten days of Farvardigann, beginning with the 26th of Abānmāh (and thus continued into Āzār-māh). On the first of Āzār-māh, he also mentions an old Iranian festival, the Kūsih bar-nishīn, a festival of reversal which al-Farghānī calls in Arabic Rukūb al-kusaj ${ }^{31}$. Finally, the five supplementary days are added to the end of Ābān-māh (the eighth month). He names them with the classical expression andarjāhāt ${ }^{32}$. This is clearly an Arabicized form of middle Persian anadargāh. Gāh stems here from oir. Gāeā.

Now, a few remarks about the Persian calendar as it appears in al-Farghānīs text will be provided. The first comment deals with the form of the ancient Zoroastrian calendar as it is given in the Elements of Astronomy. Before answering this, one should be aware that the Sogdian, the Armenian, and the Khwārizmian calendars represent the older stages of the Iranian calendar, since they themselves are of Iranian origin. The Iranian calendars followed in their historical development the history of the Iranian State(s) and was, therefore, subject to basic changes. So, the calendars of theselands,

31 See de Jong 1997, 382, footnote 94.

32 For the other names see Boyce 1970, 517ff., spec. footnote 34; and de Blois 1996, footnote 7, according to Henning from al-Bīrūnī; one common designation in Persian is duzdìda, meaning "stolen". separated from the State, are "pre-reform"33. The fact that Christians took over the Iranian month-names should not astonish, especially if one considers the Eastern Christians under Sasanian rule who adopted an Iranian feast for the New Year. In Syriac, the feast is named with the Iranian dialect form nausardel (Taqizadeh 1940). Also, the Cappadocian Calendar which is attested to in Roman times (late Republic), was probably forgotten by this time; it is the Julian calendar where only the month-names are Persian. This was an expression of the identity of the local elite from the region who claimed Iranian descent. This is similar to the contemporary calendar of $\operatorname{Iran}^{34}$.

Interestingly enough, al-Farghānī shows no trace of a thirteenth month for intercalation. This confirms de Blois' thesis $(1996,39)$ of assigning the information about Iranian pre-Islamic intercalations as they appear in al-Bīrūnì etc., to fiction. The guide fossil for assessing this, however, is the placement of the five additional days as listed by al-Farghānī. These are as follows: ahandjāh, ashandjāh, isfandārmazjāh (derived from the Zoroastrian goddess Spəntā. Mainyū + Gāèà), akhashtarjāh, and hashoshatjāh. All of these five names derive from those of the five most holy Gā $\theta$ ās, the hymns by Zarthustra. This identification took place sometimes after Alexander and before Islam. The form under which they appear here in al-Farghānī's work contrasts from the Middle Persian form in a remarkable manner. This is due to the misreading of the correspondent Pahlavi Forms; which means that our author knew this language but in an imperfect form ${ }^{35}$.

The way in which the ten days of Farvardīnjāh is explained by al-Farghānī is also of importance. He maintains that the five days that are added to the end of Ābān-māh, should

33 De Blois 1996, 46ff, esp. the "synoptic table" on p. 48 .

34 Bickermann 1967, 198 and footnote 6; and Panaino et al. 1990.

35 We want to thank Prof. M. Macuch (Freie Universität Berlin) for her useful remarks concerning this point.

Antigüedad y Cristianismo 38, 203-217, 2021 doi.org/10.6018/ayc.471611 
not be counted (lāta uddminal-shuhūr). A word should also be said about the significance of this festival, fravashis ${ }^{36}$. It is mentioned in the notice of a Byzantine ambassador to the Sasanian court towards the end of the sixth century, which is attested to by the Byzantine historian Menander Protektor (d. after 582), and falls under the third of March of the year 565 CE ("Yazdgird early"). We are informed that he was sent by his emperor towards the Persian border at Dara in Syria, because at Nisibis (Persian since 363) they celebrated a kind of obsequies which the Greek author calls "Furdigan" which is (apart from the vowels) the same form that appears in the Syriac martyrion of George ${ }^{37}$. The festival prevented any type of official business from being conducted. So, according to de Blois (1996), a second reform of the calendar of Ancient Iran took place probably in the reign of Kavādh. This reform separated the Persian (Sasanian) calendar proper from the other Iranian ones (Armenian, etc.). This can be deduced from the aforementioned Syriac Martyrion ${ }^{38}$, where we read that the festival of Farvardīgān fell in the thirtieth year of king Kavādh in the Syrian month Adhar, i.e., in March. In the year 518 $\mathrm{CE}$, the Iranian Adhar (and thus also Nawrūz) began on 17th of March, which means that the andargāh-days should begin on Ābān-māh 26. This is exactly where al-Farghānī has them ${ }^{39}$. $\mathrm{He}$ is evidently using the "Yazdgird early" era here once again. This era counted from the Hijra onwards, and the presence of two exact correspondences confirms the hypothesis that it goes back to pre-Islamic Persia.

36 The difference between Farvardīn and Fravashīsis due to different pronunciations of the Awesta.

37 Doblhofer 1955, 121ff. with the commentary on p. 216. As Gray (1904) has shown many decades ago, the Byzantines were well informed about Iranian timereckoning.

38 Hoffmann 1880, 79.

39 DeBlois 1996, 41 with notes; 46f. with notes. The "stolen days" began but after $\bar{A} b \bar{a} n$ 30; so al-Farghānī counts the period of ten days at the year's end correctly: five days in $\bar{A} b \bar{a} n+$ five days outside the regular timereckoning.

\section{(4) Coptic Calendar}

Al-Farghānīs treatment of the Coptic month-names (shuhūr al-qibț) follows again with the same phrase-structure. The Iranian calendars underwent several stages of reform after the Egyptian calendar was introduced in a special Iranian way after the conquest of that country by the Achaemenid Cambyses in 525 BC. De Blois $(1996,49)$ accepts the time span that falls roughly between 481 and 479 BC, i.e., under Xerxes for this innovation. The anadargāh corresponds clearly to the five additional Egyptian days that are called $\dot{\varepsilon} \pi \alpha$ ó $\mu \varepsilon v \alpha$ by the Greeks (and al-Farghānī, v. infra). Our author calls them "Coptic" 40 . Also, the thirty gods presiding on every single day of the month brings to mind the Egyptian decani. Moreover, the names for the weeks (of ten days) represent gods (something unknown to Greeks). But it must be stressed that the Old Egyptian decani presided over ten days, so their number resulted 36 for each year plus the additional days ${ }^{41}$.

As the Coptic month-names are concerned, the manuscripts of al-Farghānī display significant differences in about half of the names. This is already noted by Jakob Christmann $(1590,189)$ in his commentary, but at his time, there was no Coptic dialectology. For the first name, also the beginning of the Egyptian calendar, we read in all known manuscripts twt, but for the second one, instead of $\mathrm{f}^{\prime}$ wfy, some manuscripts read $b^{\prime}$ 'bh. By the same token, we find:

kywqy replaced by kyhk

m'khyr by mshyr

40 One should be cautious when using the term "Coptic". Ptolemy uses the Egyptian month-names regularly in the Greek form as was the custom since the Ptolemies. "Coptic" is a language whose use was independent from the modern Coptic Miaphysite Church during Late Antiquity (miaphysite authors normally wrote in Greek).

41 See Bickerman 1967, 29. The decani used to get established by the priests according to the star closest to the rising sun. This changed during the course of the year. The main difference is that the course of the gods is the same every month for Zoroastrianism, unheard of also in the Roman calendar with its many feasts. 
f'mynwt by brmhwt (sic!)

frmwt by brmwdh

b'khwn by bshns (sic)

The solution for this duplicity can be resolved by using the dictionary by Crum, the handbooks by Grumel and Ginzel, and the dictionary by Preisigke. The second forms of the list given above correspond with the standard Arabic forms, while the first forms are closer to the Graeco-Coptic month-names as used by Ptolemy (e. g. ed. Heiberg: $256 ; 472$; $256 ; 315 ; 329 ; 204 / 345 ; 362 ; 369 ; 205 ; 374 ; 332$; $344)$, as well as to the genuine Coptic names as given by Crum (Saidic or Bohairic) ${ }^{42}$. These names always appear with the different and various names that exist in the diverse Coptic dialects; there is no standard Coptic language. One should also take into account that the Coptic language does not differentiate between voiced and voiceless stops (as can be seen by the many spellings of Greek words). Aspiratae, like Greek X, are also used without phonemic correspondence ${ }^{43}$.

To analyse one example: The name of the fourth name is given as $\mathrm{kyw}^{\prime} \mathrm{qy}$ in one group of manuscripts. This corresponds clearly to the form used by Ptolemy: Xoïák. Looking into Crum's dictionary we find that there is a spirant in the Coptic, which the Greeks had no

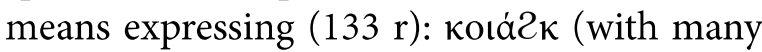
variants). But it is this form that creates the background of the standard Arabic form in kyhk, as given by Crum, and it also appears in some manuscripts of the Elements of Astronomy. The first form given by our author is therefore closer to the Greek, i.e., the one used by Ptolemy and his colleagues. The second forms are closer to those of the standard Arabic. This is no exception. If one compares the pages in $\mathrm{Crum}^{44}$, the Arabic forms given there are

42 The thesis in de Blois 2000 (VI: "The Coptic calendar"), that the Coptic month names in Islamic sources are all Saidic, is wrong.

43 Especially in Northern Coptic (Bohairic), the aspiratae are used when the article is united with the following consonant; this is the most conspicuous difference with Saidic.

44 According to the order of the months inside the the same as those in the more recent group of manuscripts of al-Farghānī. These differences are, therefore, not orthographic mistakes (which also occur, v. supra), but represent two distinct branches of the manuscript tradition. It is quite probable that they were put there later by somebody who knew the standard forms. The source for the standard forms which are closer to the Coptic variants, come from works of other astronomers or the Egyptian chancery, who used these forms in Arabic (even today). Our author then, working in Baghdad, stayed close to his master, Ptolemy. There were few if any Copts in the capital. These recent forms are identical with those given by al-Battānī (fl. c. $260 \mathrm{AH} /$ c. $880 \mathrm{CE}$ ) and al-Bīrūnī, so we can follow a process of homogenization of our author's work by the way of his transmission. That Gerhard of Cremona's translation shows the same innovation ${ }^{45}$ (if one uses the edition by Campani) shows that the secondary redaction of al-Farghānī’s work already existed in the 12th century and was common in alAndalus. This duplicity of the manuscripts can also probably be explained in an historical context; considering the fact that al-Farghānī was commissioned by caliph al-Mutawakkil to construct a Nilometer in Cairo, it is very well likely that he himself was responsible for such a replacement of the names. This possibility falls in line with his interest in practicality, that is reflected in his text and is discussed more broadly above.

\section{Concluding Remark}

Chronology and calendrical knowledge in the ninth century Islamic era were seen at the interface of astral sciences and civil

Egyptian year, these are the following: 462 1; $266 \mathrm{r} ; 728$ 1; 133 r (v. supra); 397 r; 206 l; 269 l (bis); 279 l; 263l; 57 r; $186 \mathrm{r}$.

45 The forms in Gerhard's version (1910, 60, ed. Campani) are: teut, bebih, athur, kiak, tubih, amsir, barmaheh, barmadea, bastames, baunih, abib, mescerim. The editor based his text only on the Florentinus Mediceus Plut. 29/9 and did not correct graphical errors and misreadings. Nevertheless, we are dealing with the secondary names here without doubt. 
requirements which served as a vehicle for the engagement of astronomers in administrative activities. Their entrance in the circle of courtier projectors encouraged them to write for a broader audience and reassert their research. This is exactly what we find in the readership of al-Farghānīs Elements of Astronomy, where the material is presented clearly in a wellorganized and eloquent manner. Al-Farghānīs text, therefore, reflects a change in priorities in the intellectual activities of the early Islamic astronomers. It depicts them not only as scientists and theoreticians, but also as social actors who participated in and helped to create the official regulations of that era. Our study stresses the relationship between scientific disciplines and socio-political orientations and the transformation of scholarly knowledge into public programming in the classical centuries of Islam. The Elements of Astronomy, besides being an important contribution for the reception and dissemination of Ptolemaic astronomy, proves to be a witness for the development of Greek tradition into something unmatched in the pre-Islamic world: controlling taxation system in a multi-cultural empire. These aspects of the transmission and transformation of astronomical sciences in the early Islamic time should be noted for future research.

\section{BibLIOGRAFÍA}

Bagheri, M. 2006. Kūshyār b. Labbān's Account of Calendars in His Jāmi'Zīj. Journal for the History of Arabic Science 14, 1 - 40.

Bickerman, E. J. 1967. The 'Zoroastrian' Calendar. Archív orientální 35, 197 - 207.

al-Bīrūnī, A. R. 1878. Chronologie Orientalischer Völker (al-Āthār al-bāqiyya 'an al-qurūn alkhāliyya). Ed. by Sachau, E. Leipzig: Brockhaus in Commission. Reprinted in Frankfurt am Main: Publications of the Institute for the History of Arabic-Islamic Science. Islamic Mathematics and Astronomy 30.

al-Bīrūnī, A. R. 1974. Kitāb al-Tafhìm li-awà'ìșinā at al-tanjīm. Ed. by Humā'ì, J. Tehran: Anjuman-i Āthār-i millì.

Boyce, M. 1970. On the Calendar of the Zoroastrian Feasts. Bulletin of the School of Oriental and African Studies 33, 513 - 539.

Brockelmann, C. 1895. Lexicon Syriacum. Edinburgh - Berlin: T. \& T. Clark - Reuther \& Reichard.

Campani, R. (ed.), and Alfragano (Al-Farghānī). 1910. Il 'Libro dell'aggregazione delle stelle'. Città di Castello: S. Lapi.

Carmody, F. 1956. Arabic Astronomical and Astrological Sciences in Latin Translation: A Critical Bibliography. Berkeley: University of California Press.

Christmann, M. J. 1590. Muhamedis Alfragani arabis, Chronologica et astronomica elementa et palatinae bibliothecae veteribus libris versa expleta et scholiis expolita. Frankfurt.

Crum, W. E. 1939. A Coptic Dictionary. Oxford: Clarendon Press.

de Blois, F. 1996. The Persian Calendar. Iran 34, 39 - 54.

de Blois, F. 2000. Ta' rikh (part I-1: Dates and eras in the Islamic world; in the sense of "date, dating", etc.). Encyclopedia of Islam. 2nd edition. Vol. 10, 257 - 264. Leiden: Brill.

de Jong, A. F. 1997. Traditions of the Magi: Zoroastrianism in Greek and Latin Literature. Leiden: Brill.

Doblhofer, E. 1955. Byzantinische Diplomaten und östliche Barbaren: aus den Excerpta de legationibus des Kontantinos Porphyrogennetos ausgewählte Abschnitte des Priskos und Menander Protektor. Graz: Styria.

Drower, E. S. and Macuch R. 1963. A Mandaic Dictionary. Oxford: Clarendon Press. 
Ginzel, F. K. 1906-1914. Handbuch der mathematischen und technischen Chronologie: das Zeitrechnungswesen der Völker. 3 vols. Leipzig: Hinrichs.

Goldstein, B. R. 1967. Ibn al-Muthannā’s Commentary on the Astronomical Tables of al-Khwārizmī. New Haven: Yale University Press.

Gray, L. H. 1904. Mediaeval Greek References to the Avestan Calendar. In Avesta, Pahlavi, and Ancient Persian Studies: in Honour of the Late Shams-ul-Ulama Dastur Peshotanji Behramji Sanjana, 167-175. Strassburg - Wiesbaden: K. J. Trübner - Otto Harrasowitz.

Grumel, V. 1958. La chronologie. Paris : Presses Universitaires de France.

Heiberg, J. L. (ed.), and Ptolemy. 1903. Syntaxis Mathematica. 2 vols. Leipzig: Teubner.

Hoffmann, G. 1880. Auszüge aus syrischen Akten persischer Märtyrer, übersetzt und durch Untersuchungen zur historischen Topographie erläutert. Leipzig: Brockhaus.

Ibn al-Qifțī. 1903. Tä'rīkh al-Hukamā'. Ed. by Lippert, J. Leipzig: Dieterich'sche Verlagsbuchhandlung.

Ibn Wahb, I. K. 1967. al-Burhān fì wujūh al-bayān. Ed. by Mațlūb, A. and al-Ḥadīthī, Kh. Baghdad: University of Baghdad.

Kennedy, E. S. 1989. A Survey of Islamic Astronomical Tables. Philadelphia: American Philosophical Society.

Kubiak, A., Jakubiak, K. 2012. Unpublished inscriptions from Palmyra. Semitica et Classica 5, $229-234$.

Lampe, G. W. H. 1961. A Patristic Greek Lexicon. Oxford: Clarendon Press.

Lewy, H. 1941. Le calendrier perse. Orientalia 10, 1 - 64.

Mas' ūdī, Sh. D. 2003. Jahān-e dānish. Ed. by Zanjani, D. A. Tehran: Mīrās-e Maktūb.

Minns, E. H. 1915. Parchments of the Parthian Period from Avroman in Kurdistan. The Journal of Hellenic Studies 35, $22-65$.

Nallino, C. A. 1911. 'Ilm al-falaktā'rìkhuhu'ind al- 'arabfì al-qrūn al-wusța (in Arabic). Rome: Maktab al-Dār al- 'Arabiyya li al-kitāb.

Neugebauer, O. E. 1962. The Astronomical Tables of al-Khwārzimì. Translation with Commentaries of the Latin Version edited by H. Suter supplemented by Corpus Christi College MS 283. Copenhagen: i kommission hos Ejnar Munksgaard.

Panaino, A., Abdollahy, R. and Balland D. 1990. Calendars. Encyclopaedia Iranica IV/6-7: 658-677. Available online: http://www.iranicaonline.org/articles/calendars. Last accessed: 01/07/2020.

Pingree, D. 1968. The Fragments of the Works of Ya 'qūb Ibn Țāriq. Journal of Near Eastern Studies 27 (2), 97 - 125.

Preisigke, F. 1925-1931. Wörterbuch der griechischen Papyrusurkunden: mit Einschluß der griechischen Inschriften, Aufschriften, Ostraka, Mumienschilder usw. aus Ägypten. 3 vols. Berlin: Selbstverlag der Erben.

Al-Qalqashandī, 'A. 1913-1922. Ṣubḥ al-a 'shā. Ed. by Ibrāhīm, M. 'A. 14 vols. Cairo: Dār alKutub al-Mișriyya.

Sabra, A. I. 1971. Al-Farghānī. In Gillispie, Ch. C. (ed.), Dictionary of Scientific Biography, vol. 4, 541 - 545. New York: Charles Scribner's Sons.

Șā id al-Andalusī. 1997. al-Ta' rîf bi-țabaqāt al-umam: tārīkh-i jahānī-i 'ulūm va dānishmandān tā qarn-i panjum-i Hijrī. Ed. by Jamshīdnizhād, Gh. R. Tehran: Mīrās-e Maktūb. initial

Shahmardān, I. A. K. 2003. Rawụat al-Munajjimīn. Ed. by Zanjānī, J. A. Tehran: Mīrās-e Maktūb.

Taqizadeh, S. H. 1937. Gāhshumārī dar İrān-e qadìm (Chronology in ancient Iran). Tehran: Chāpkhāne-ye Majlis.

Taqizadeh S. H. 1939a. Various eras and calendars used in the countries of Islam. Bulletin of the School of Oriental studies 9 (4), 903 - 922. 
Taquizadeh, S. H. 1939b. Various Eras and Calendars Used in the Countries of Islam (Continued). Bulletin of the School of Oriental and African Studies 10 (1), 107 - 132.

Taqizadeh, S. H. 1940. The Iranian Festivals Adopted by the Christians. Bulletin of the School of Oriental and African Studies 10 (3), 632 - 653.

van Dalen, B. 1996. Al-Khwārizmī’s Astronomical Tables Revisited: Analysis of the Equation of Time. In Casulleras, J. and Samsó, J. (eds.), From Baghdad to Barcelona: Studies in the Islamic Exact Sciences in Honour of Prof. Juan Vernet, vol. 1, 195 - 252. Barcelona: Instituto Millas Vallicrosa de Historia de la Ciencia Arabe.

van Dalen, B. 2000. Ta' rikh (part I-2: Date s and eras in the Islamic world; Era chronology in astronomical handbooks). Encyclopedia of Islam, 2nd edition, vol. 10, 264 - 271. Leiden: Brill. Wiet, G. (ed.). 1924. Maqrîzî: El-mawâ 'iz wa'l-i 'tibâr fî dhikr el-khitat wa'l-âthâr, vol. 4. Cairo: l'Institut français d'archéologie orientale. 


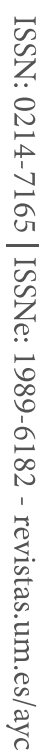


UNIVERSIDAD DE MURCIA

GRUPO DE INVESTIG $\Lambda$ CIÓN " $\Lambda$ NTIGÜEDAD Y CRISTIANISMO" www.um.es/antiguedadycristianismo

\section{edit.um \\ Ediciones de la Universidad de Murcia}

\section{cepoAt}

UNIVERSIDAD DE MURCIA

centro de estudios del

próximo oriente y la

antigüiedad tardia 